had weight in former days; at present they have none. Methylated chloroform is by no means an expensive luxury, and the admirable apparatus which Krohne and Besemann make for veterinary use in the stock farm at once renders chloroformisation simple and entails quite a trivial expenditure, as the quantity of the drug required is very small. This apparatus is in principal a large Junker's inhaler, with facepieces specially designed to meet the requirements of the stock farmer. Nor, as a matter of fact, is even this apparatus necessary ; an apparatus constructed from a nosebag answers perfectly well. Horses perbaps require more chloroform than other animals, and the cost in their case is estimated by Mr. Moore at $2 d$. per head; cattle cost far less. The troublesome stage of excitement which to the inexperienced proves a bugbear can, as Fleming and others have pointed out, be lessened or abrogated by the use of a less diluted vapour during the early stages of the anæsthesia. If " crowded on" at first, little difficulty ensues in the later stages. The danger from overdosage in horses and cattle seems, if the most experienced of our veterinary surgeons are to be trusted, quite minimal. Indeed, it is said you cannot kill a horse by chloroform inbalation. For sheep, which are subjected to most painful mutilations, chloroform can be easily employed. How any humane person can deny these patient duab things so slight a mitigation to their teleological existence it is difficult to say, unless we admit, with the poet, that "only man is vile." The operation is bettter performed and fewer hands have to be employed when chloroform is used. For castration of calves also and the "ringing " both of bulls and swine chloroform has been widely used, and has rendered the procedure at once more easy and more scientific. Firing of horses is now, notably in the case of favourite hunters, commonly performed under the anæsthetic, and certainly no man can be called merciful who is not "merciful to his beast" in the matter of chloroform. A further point, and one of no slight importance, is the much better results which follow operations undertaken upon animals which have been chloroformed. In a report before me $I$ find that lambs so treated compared most favourably with those subjected to the barbarous handling in vogue in less enlightened farms, while the same may be said with regard to horses and cattle. The rough-and-tumble butchery of the pre-chloroform era of veterinary surgery has little to commend it when compared with the precise methods and accurate results obtained by scientific exponents of veterinary surgery such as can be arrived at by the aid of chloroform. If owners of horses and farm stock and of pets once realised that chloroform for their animals meant not only immunity from pain, but also ensured better results and less risk of failure or accident, there is no donbt that they would insist upon the use of the anæsthetic, and would see that it was given $\in$ fficiently and in the best way. I am, Sirs, yours faithfully,

April 10th, 1895. AN ALSTHETIST.

\section{FATAL HUMAN GLANDERS FROM A NON- FATAL CASE IN THE HORSE.}

\section{To the Eiditors of THE LANCET.}

SIRs,-Mr. Garstang's interesting paper on Glanders ${ }^{1}$ is a raluable addition to our knowledge of the causation and treatment of that disease. In it he proves that a non-fatal case of discharge from the nostrils of a horse is capable of producing glanders in the human subject, a fact which, though not anknown, is too often lost sight of by medical practitioners as well as by the public. For that reason the following fatal case may be of interest. On May 26th, 1894, I saw a man in consultation with his usual attendant. He then showed the well-known signs of chronic glanders, and on making inquiries I found that a short time before his atiack he had been in charge of a horse that suffered from symptoms of general disease with nasal discharge, from which, however, the animal recovered. The point of infection in our patient was on the upper lip, and the submaxillary and cervical glands became quickly affected, those of other parts of the body being subsequently implicated. The patient was afterwards removed to Cork, where be died with symptoms of pyæmia. Dr. T. G. Atkins of that city saw him before his death, and independently made a similar diagnosis of chronic glanders. A medical man who examined the patient also acknowledged that the attack was one of glanders, but did not think that it could have been con- tracted in the way I have mentioned, as in his opinion the disease is always fatal in the horse. Mr. Garstang's paper has effectually answered the latter objection, and I briefly allude to the above case as it supports the view so clearly propounded in the article referred to and proves the need for greater care in the handling of horses suffering from any discharge from the nostrils.-I am, Sirs, yours faithfully, Bandon, April 11th, 1895.

J. J. WELPLY.

\section{THE PREVENTION OF SMALL-POX.} To the Editors of THE LANCET.

SIRs,-Seeing so much in THE LANCeT lately as to the etiology and prevention of small-pox, I think a short account of the ideas entertained by the Dyaks of Borneo on the subject, and of the mode of application of them byone of their number, might prove amusing, if not instructive, to some of: your readers. In the year 1889, while acting as principal medical officer to the Sarawak Government a case of smallpox occurred among the Sarawak Rangers, a corps composed of Sea Dyaks. The case was isolated, and the whole corps (as I thought) was vaccinated. Three or four, I forget which, other cases occurred, only one of which was confluent, and which proved fatal. I afterwards got the following history of this case from the sergeant-major. The Dyaks believe that a devil presides over each epidemic disease, but are not so smart but that a clever Dyak might trick them. While I was vaccinating he slipped over from the unvaccinated to the vaccinated group without being noticed, and told his companions that in such a crowd the "small-pox devil " would never notice it, but think that he had been vaccinated with the rest. The Dyaks said that the "devil" was sharper than the man; I attributed it to non-vaccination, but the Anti-Vaccination League would probably say it was a mere coincidence.-I am, Sirs, yours truly,

$$
\text { J. WIDMER RoLPH, }
$$

Kuantan, Pahang, March 6th, 1895. Medical Officer, Pahang Corporation, Limited.

\section{"THE TITLE OF 'DOCTOR."}

\section{To the Editors of THE LANCET.}

SIRS,--Dr. Campbell Black infers from my letter more than he has any right to do, and evades my contention. I stated that so far as I had been able to ascertain the title of "Dr." as applied to medical men was a "courtesy" one, on a par with that of "Rev." amongst divines, and that no legat" question was involved. I also pointed out that Dr. Black would do better to spend a little money in satisfying himself as to the legal question if still in doubt about it. I am so satisfied on the point that I do not care to do it. I very seldom use the title of "Dr." myself, and have a door-plate inscribed "Physician and Surgeon." If, however, this quibble about a courtesy title is carried much further II shall be inclined to ask whether the M.D. confers the title of Physician without the sanction of one of the Royal Colleges. I believe it nsed not to do so. The whole squabble appears to me puerile and unworthy. Why cannot Dr. Black and others unite with us in our battle against real abuses, such as that of "medical charities," that of "medical aids," and the general tendency to depreciate and undervalue medical services? Surely this would be better than tilting against windmills, and if Dr. Black will do this I care not whether he calls me "Dr." or "Mr." ; but he should not assume a knowledge of the amount of brass in my door-plate from a general statement of opinion on an open subject.

I am, Sirs, your obedient servant. Loughborough, April 11th, 1895. J. B. PIKE.

P.S.-I may say that in communications from the Royal College of Physicians of Edinburgh I bave repeatedly been addressed as "Dr.," and, knowing the position the College takes on the subject, have written to complain of the indignity, which, however, shows the common castom of using the courtesy title.

\section{"A MODERN IMMORTAL." To the Editors of THE LANCHT.}

SIRS, - In an annotation headed "A Modern Immortal," which appeared in THE LANCET of Feb. 9th, 1895, the credit 
of the discovery of anæsthesia is given to Morton of Massachusetts- "Morton, to whom belonged the immortal honour of having been the first to demonstrate that prolonged anæsthesia could be safely produced by means of ether." It is simply for the sake of justice and truth that I write to declare that there is strong evidence to show that Dr. Crawford $W$. Long, practising in the town of Jefferson, in the State of Georgia, deserves the credit of having been the discoverer of prolonged anæsthesia by means of ether. His first operation under ether narcosis was done in March, 1842-four years before the time of the supposed discovery by Morton. The facts of the case are well brought out by Dr. Luther B. Grandy, ${ }^{1}$ of Atlanta, Va., in an article in the Virginia Medioal Monthly, October, 1893, by means of which he was forced into a contest with Dr. W. R. Hayden (of viburnum compound fame), who bitterly urged the counterclaim of Morton. As an evidence of the great amount of doubt in regard to Morton's claims of priority there is a white marble monument in Boston (where Morton publicly made known his supposed discovery) which bears the simple inscription: "To the Discoverer of Anæsthesia." Does that show that it is acknowledged, even by the people who saw what was done, that Morton was the discoverer? On the contrary, there stands in Paris a marble statue of Crawford W. Long, an enduring witness to the truth; and the Georgia Lagislatare will place his statue in the National Gallery of Statues in Washington as a fitting recognition of the immortal greatness of her son. Marion Sims published a piece on the subject in the Virginia Medisal Monthly, May, 1877, in which it is demonstrated beyond practical doubt that Long is the true "modern immortal." It is in the interest of all science that the truth be known, and that not the slightest deviation from it be allowed; and I hope that in this case the truth will surely prevail. Fiat justitia, ruat colum.

I am, Sirs, yours very sincerely,

Lynchburg, Va., March 13th, 1895. S. P. Preston, M.D.

\section{"PROVISION FOR YOUNG IMBECILES." \\ To the Editors of THE LANCET.}

SIRS, - As a guardian of the poor in a country union I ask to be allowed to say a few words in confirmation of the needs of which Dr. Shnttleworth has written. On coming to a country union from the metropolitan district I was astonished to find that no provision was made for idiots or imbeciles beyond the county lunatic asylums for adalts. I found idiot children running about in the sick wards of the workhouse without any special care or attempt at training, while in a London union they would at once have been sent off to Darenth. This difference in the mode of treatment between London and the country I am utterly unable to understand; the children can only become worse till they are hopeless and have to be sent to the asylum for adult lunatics. Inquiries at all the county asylums for idiots showed that two or three were willing to take pauper children who were thought to be capable of improvement, and after much trouble I succeeded in getting two sent to the asylum at Star-cross, a journey of great expense, and with accommodation entirely inadequate to the needs of all the southern counties. As the subject has been discussed by Poor-law authorities during many years it is almost incredible that no action has yet been taken; we can only go on stating facts till the county councils are impressed with the need of establishing asylams sufficient for the needs, not only of pauper children, but of others also who by timely training might be saved from becoming life-long burdens on the rates. But in asking for educational asylums I would not limit the demand to the most hopeful of the children in workhouses. I would like to see all idiots and imbeciles removed, for the nurses in those institutions are far too few to be able to take proper care of them, and are already in almost all instances overworked. Let the worst as well as the best among them be removed and classified in an asylum, where each and all could have the best care and not be placed, as I bave seen them, in wards with lunatics and adults. I would only add that the opening of many more schools or homes for the feebleminded, who can hardly be classed with either idiots or imbeciles, is urgently called for, the two or three already existing being utterly inadequate for the number of such to be found in every workhouse and pauper school, and who are

I Virginia Merlical Monthly, October, 1893, February, 1894, Marcl 1894, and June, 1894. unable to benefit by the instruction given there. I may add that I am convinced the numbers far exceed those given in the recent report of the Local Government Board.

April 11th, 1895.

I am, Sirs, yours faithfully,

LOUISA TWINING.

\section{"THE RESULTS UPON THE TESTICLE OF \\ IIGATURE OR DIVISION OF THE VAS DEFERENS." \\ To the Editors of THE LANCET.}

Sins, -At the conclusion of his interesting lecture on the above subject, published in THE LANCET of April 13th, Dr. Joseph Griffiths deals briefly with the matter as affecting man, and sums up as follows: "It would hence seem that mere division, ligature, or occlasion of the vas deferens does not lead to atrophy of the seminal tubules; but if in case of division there is, in addition, some damage to the other structures of the cord, destructive changes, followed by atrophy and ultimate disappearance of the seminal cells, are liable to occur." As baving a practical bearing upon this question, may I be allowed to call attention to a short communication which I published in THE LANCET of March 7th, 1891, upon "The Effect of the Division of Certain Constituents of the Spermatic Cord "\&c.? In that communication I recorded three cases in which to my knowledge not only the vas deferens but also the spermatic veins and artery, with the other structures which go to complete the formation of what is commonly designated the spermatio cord, had been completely divided without any apparent damaging $\in$ ffect apon the nutrition of the testicle, a condition of things of which, so far as I am aware, no previons mention had been made in surgical literature. From these cases and from some other evidence which had come under my notice I drew the following deduction: "that division of the vas deferens, spermatic veins, and spermatic artery [i.e., practically the whole spermatic cord] is not necessarily followed by sloughing or eren by subsequent wasting of the testicle provided that a perfoctly aseptic condition of the wound is maintained." At the date of my communication the time which had elapsed since the division of the structures indicated was not, perhaps, sufficient to permit of a reliable prognosis as to the final condition of the testicle in these cases. I have, how. ever, quite recently bad an opportunity for examining one of the patients concerned, and found the testicle (more than four years after the division of the cord) of normal size and consistence, and with its peculiar sensation indistinguishable in character and intensity from that of the opposite organ. The fact that I am unaware of any similar instance baving been recorded is my main excuse for troubling you with this letter. I am, Sirs, yours faithfully,

Chesterfield-street, Mayfair, W., April 15th, 1895. WILLIAM H. BENNETI

\section{"POLEX IRRITANS."}

To the Editors of THE LANOET.

SrRs, - In your annotation in THE LANCET of April 6th regarding the means of destroying this irritating pest one plan not mentioned upon one occasion gave exceptionally good results. The matting of my bungalow in Java suddenly became infected with myriads of fleas, so numerous that the legs, covered only with loose white trousers, were instantly coated with a living mass. Strong quassia tea was freely used as a wash to the mat-covered floors, and the swarms vanished as by magic.-I am, Sirs, yours truly, April, 1895.

RICHARD NEALE, M.D. Iond

\section{"ILLEGAL VACCINATTON."}

To the Editors of THE LANCET.

SIRs, - In the annotation under the above heading in THB LANCET of April 13th you deplore the increase of irregular and inefficient vaccination. That such an increase is a stern reality and franght with most pernicious consequences must be the experience of every general practitioner, however limited his experience may be. After pointing out the extreme laxity with which the term "successful" is used in its application to vaccination you further add: "The small-pox statistics of the past decade would have presented a different aspect than ther 